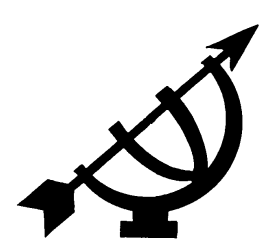

\title{
Aftrede as integrasionele taak
}

\author{
A.R. Brunsdon \& G.A. Lotter \\ Praktiese Teologie \\ Potchefstroomkampus \\ Noordwes-Universiteit \\ POTCHEFSTROOM \\ E-pos: arbrunsdon@gmail.com \\ lotter@nwu.ac.za
}

\begin{abstract}
Retirement as integrational task

In this article, the stance is taken that retirement can be viewed as a critical life phase. Depending on how retirees cope with this phase, they can either experience feelings of futility or engage in an optimal use of this promising period. The critical task of the retirement phase could therefore be outlined as achieving a deep sense of fulfillment and optimisation of lifeopportunities during the so-called golden years. This article will explore retirement as integrational task, the challenge being to guide retirees to an integration of life and faith experiences in order to experience meaning. A narrative approach to pastoral care is suggested as a mode for integration as it takes the generated experiences (stories) of people seriously. Within a reformational view of the narrative the Word of God is also taken seriously. In this fusion between the Story of God and man's story lies the integration which will result in the creation of meaning during the final stage of man's journey through life.
\end{abstract}

\section{Opsomming}

\section{Aftrede as integrasionele taak}

In hierdie artikel word van die standpunt uitgegaan dat aftrede as 'n kritiese lewensfase beskou kan word. Dit beteken dat afgetredenes, onderhewig aan hoe hulle hierdie lewensfase hanteer, óf in futiliteit kan verval, óf hierdie lewensfase optimaal kan benut. Hiermee is die kritiese taak van aftrede omlyn as die optimale benutting van dié lewensfase. Hierdie artikel ondersoek die moontlikheid om aftrede as integrasionele taak te benader. Die uitdaging hiervan sou wees om afgetredenes wat neig na gevoelens van futiliteit te lei tot 'n sinvolle integrasie 
van hulle lewenservaring en geloofskennis sodat hulle sin tydens aftrede kan beleef. Die narratiewe benadering tot die pastoraat kan moontlik hiervoor 'n goeie voertuig bied, aangesien dit die verhale van mense benut. Vanuit 'n reformatoriese benadering tot die narratiewe terapie werk dit ook met die Godsverhaal waarbinne die lewe en die mens 'n andersoortige sin en potensiaal het. Die artikel dui aan dat afgetredenes via die narratiewe pastoraat tot integrasie van hulle eie verhale en die Godsverhaal kan kom. In hierdie integrasie lê een van die sleutels tot volle sinsontsluiting en hoop tydens een van die lewe se mees uitdagende fases.

\section{Inleiding}

Die relevansie van 'n effektiewe pastorale bediening aan senior persone ten einde hulle te begelei tot 'n optimale realisering van hulle gawes en menswees gedurende aftrede, blyk uit 'n aantal faktore. Enersyds wil dit voorkom of die getal senior burgers aan die toeneem is in sommige segmente van die Suid-Afrikaanse bevolking. In een van die hoofstroom Suid-Afrikaanse kerke, die Nederduitse Gereformeerde Kerk, was 22\% van die lidmate in 2006 ouer as 60 (Schoeman, 2008:6). Dit beteken dat lidmate ouer as 60 in dié kerk byna in ewetal met dooplidmate jonger as sestien is. Andersyds blyk die pastorale bediening aan afgetredenes belangrik te wees in die lig van wetenskaplike nadenke oor aftrede as 'n lewensfase. Vroeëre refleksie oor menslike ontwikkeling, soos gesien in die ontwikkelingsteorie van Erikson (1965:239-261), het gesuggereer dat persone in hierdie fase kan verval in 'n lewensgevoel van futiliteit. Meer resente refleksie oor aftrede wil dit egter hê dat afgetredenes deel is van die sogenaamde "active/productive aging"beweging. Hierbinne word aftrede verstaan as 'n positiewe lewensfase waarbinne nuwe lewensmoontlikhede ontgin word (Kaye, 2005:3).

Of afgetredenes binne die Suid-Afrikaanse konteks al die skuif gemaak het vanaf die tradisionele siening van aftrede as ontkoppeling (Ebershole \& Hess, 1990:39) na 'n meer aktiewe aftrede, is 'n ope vraag. Hierdie artikel ontgin die moontlikheid om aftrede as 'n integrasionele taak te benader. Dit word gedoen deur 'n narratiefpastorale model te konstrueer waarmee afgetredenes begelei kan word tot 'n sinvolle integrasie van hulle eie lewensverhale in die lig van die Godsverhaal wat hulle sal motiveer om optimaal binne hierdie lewensfase te funksioneer. Die narratiewe benadering tot die pastoraat word ondersoek as die modus waarmee hierdie integrasionele taak gefasiliteer kan word. Afgetredenes beskik as gevolg 
van hulle lewensjare oor 'n ryk verhaleskat. Aangesien die narratiewe benadering tot die pastoraat werk met mens- en Godsverhale (Van den Berg, 2006:175-176), kan hier 'n samesmelting wees wat die navorsingsonderwerp sinvol kan dien. Hopelik kan dit meewerk tot 'n pastoraat wat afgetredenes sal stimuleer tot 'n sinvolle ontginning van die sogenaamde goue jare.

Metodologies sal die navorsing by Zerfass (1974:166 e.v.) se model vir die praktiese teologie aansluit. Hiervolgens word met basis-, meta- en praktykteorie gewerk om by die navorsingsresultate uit te kom. Alhoewel krities opgemerk kan word dat Zerfass se benadering nie 'n resente prakties-teologiese model verteenwoordig nie, verreken dit steeds die kernelemente waarmee daar binne 'n praktiesteologiese model gewerk moet word. Lotter (2007:5) se oorsig van jonger modelle vir die praktiese teologie, waaronder die modelle van Getz, Heitink en Lotter se eie tel, dui daarop dat hierdie benaderings in wese dieselfde kernelemente van basis-, meta- en praktykteorie omvat. De Wet (2006:58) se insette oor Zerfass se model word egter in ag geneem, naamlik dat aksentverskuiwings en spesifiserings nodig is om teologiese modelle binne 'n gereformeerde konteks te gebruik. Met gereformeerde konteks word bedoel 'n benadering tot die pastoraat wat die Woord van God as vertrekpunt neem. In die geval van hierdie artikel word daar dus oor sinsrealisering tydens aftrede besin in die lig van die openbaring van God se Woord (vgl. Van der Walt, 2007:3).

Die navorsing verloop langs die volgende weg: begripsverheldering van die volgende sentrale begrippe word gegee: aftrede as kritiese lewensfase, narratiewe terapie, narratiewe pastoraat, Skrifgebruik binne ' $n$ narratiewe pastorale benadering en aftrede as integrasionele taak. Vervolgens word aandag gegee aan basisteoretiese beginsels vir 'n integrasionele aftrede uit die boek Prediker. Metateoretiese perspektiewe op aftrede word gegee deur aftrede fenomenologies te belig. Die eietydse Suid-Afrikaanse konteks word kortliks bespreek as katalisator vir futiliteit tydens die aftreejare. Ten slotte word enkele praktykteoretiese riglyne aan die hand gedoen om aftrede as integrasionele taak te fasiliteer.

\section{Begripsomskrywings}

\subsection{Aftrede as kritiese lewensfase}

In hierdie artikel word aftrede wyer as die neerlê van die beroepstuig of die bereiking van 'n sekere ouderdom beskou. Dit word eerder verkies om van aftrede as kritiese lewensfase te praat. Indien 
aanvaar word dat individue met aftrede 'n nuwe lewenstadium betree wat met talle emosionele en fisiese aanpassings gepaard gaan (Miller, 2004:140), kan saamgestem word met die beskouing dat aftrede 'n periode vol belangrike uitdagings verteenwoordig. Die meer spesifieke gedagte van 'n kritiese lewensfase word ontleen aan die ontwikkelingsteorie van, onder andere, Erik Erikson (1965). Hy het gemeen dat persone in 'n bepaalde lewenstadium sekere sogenaamde ontwikkelingstake suksesvol moet bemeester alvorens hulle 'n volgende lewensfase kan betree. Wat aftrede as 'n kritiese lewensfase konstitueer, is die feit dat dit vanweë die afgetredene se ouderdom 'n finale lewensfase is. Indien take of doelwitte gedurende hierdie fase nie ten beste bemeester of bereik word nie, sal die afgetredene nie sy/haar potensiaal verwesenlik nie. Die gevolg hiervan kan futiliteit in die hand werk en die afgetredene laat worstel met die tergende vraag omtrent lewensin. In dié proses sal die afgetredene asook sy/haar leefomgewing armer gelaat geword.

\subsection{Narratiewe terapie}

Sedert die vroeë negentigerjare het die term narratiewe terapie die aandag van die hulpverleningswetenskappe aangegryp. Die huidige momentum van hierdie benadering kan hoofsaaklik toegeskryf word aan die werk van twee kliniese terapeute, te wete Michael White, afkomstig van Australië, en David Epston van Nieu-Seeland. Hulle gesamentlike werk, Narrative means to therapeutic ends (1990), word vir die afgelope dekade en meer as standaardwerk binne die narratiewe benadering beskou. In hierdie benadering funksioneer die begrip narratief as 'n metafoor vir die verstaan van die mens se lewe as 'n verhaal (Stassen, 2004:41).

'n Narratief (verhaal) ontstaan volgens Morgan (2000:5) in mense se lewens na aanleiding van gebeure wat in volgorde oor tyd volgens 'n bepaalde intrige ontwikkel het. Mense leef hulle lewens en laat hulle verwagtings van die lewe aan die hand van hierdie verhale bepaal. Mense se lewens is egter multistoried: "There are many stories occuring at the same time and different stories can be told about the same events." (Morgan, 2000:8.) Hierbenewens word mense se lewensverhale medebepaal deur hulle lewenskonteks en kultuur. Hierdie sogenaamde sosiale diskoerse spreek 'n bepaalde woord met lewensgebeure mee om uiteindelik die verhaal te vorm aan die hand waarvan mense hulle lewens verstaan en interpreteer.

Volgens White en Epston (1990:9-10) tref die narratiewe benadering (hierna ook genoem: narratief) tot terapie 'n onderskeid tussen die sogenaamde dominante en alternatiewe verhale. Die dominante sto- 
ries is gewoonlik die probleemdeurdrenkte verhale (problem-saturated stories) wat die alternatiewe (positiewe) verhale oorskadu. Alle nuwe gebeure word deur die lens van die dominante verhale gesien en verstaan. Dit beteken dat 'n beperkende siening op die hede en toekoms nagehou word. Die transformerende element van die narratiewe benadering lê daarin dat dit ook die alternatiewe (positiewe) verhale in mense se lewens na vore bring en versterk sodat 'n nuwe, positiewe verhaal geskep kan word waardeur die ou dominante verhaal vervang word (White \& Epston, 1990:15).

Die konstruksie van hierdie unieke uitkomste of nuwe verhale van hoop word gefasiliteer deur verskeie strategieë. Onder die mees prominente hiervan tel dekonstruksie (De Jager \& Müller, 2002: 1225, 1233), eksternalisering (O'Hanlon, 1994:23), vraagstelling wat ervaring genereer (Freedman \& Combs, 1996:113), die skryf van briewe (White \& Epston, 1990:34-37) en die sogenaamde terapeutiese houding van "not knowing - the client is the expert" (Anderson \& Goolishian, 1992:29). Wat al hierdie strategieë in gemeen het, is om die verhale van mense aan te hoor sodat nuwe verhale van hoop saam gekonstrueer kan word. "Wanneer die dinamiese interaksie tussen verlede en hede plaasvind, spring daar 'n vonk oor na die toekoms en word nuwe alternatiewe visioene van die toekoms oopgesluit." (Van Wyk \& Marais, 2005:19.)

Volgens Müller (2000:72) sou die narratief aan die hand van verskillende bewegings kon ontvou. Die noodverhaal moet op die tafel kom - verhale wat die nood van mense konstitueer. Die verledeverhaal, waarin die noodverhaal ingebed is, moet dan vertel word. Vervolgens moet die verledeverhaal hervertel word. Die uitdaging van hierdie beweging is die hervorming of herformulering van persepsies wat problematies is. Uiteindelik lei dit tot die konstruksie van ' $n$ verbeelde toekomsverhaal. Op grond van die hervertelling van die nood-/verledeverhaal word nuwe moontlikhede vir die toekoms verbeeld - dit is hoe daar nou anders geleef gaan word.

\subsection{Narratiewe pastoraat}

Uit die voorafgaande blyk duidelik dat die narratief groot belofte inhou vir persone wat vasgevang geraak het in beperkende lewensdiskoerse. Tog sou die narratiewe benadering vanweë sy filosofiese onderbou nie sonder kwalifikasie met alle vorme van hulpverlening gebruik kon word nie. Pastorale teoloë, waaronder Janse van Rensburg (2000:62; 2007:61-80), Bezuidenhout (2005) en Senekal (2006:134-146), bepleit 'n epistemologiese sensitiwiteit waarbinne die eiegoed van die pastoraat en die narratief in ag geneem behoort 
te word ten einde epistemologiese diskrepansies te vermy. Binne die gereformeerde tradisie word pastoraat tradisioneel as geloofsen lewenshulp verstaan (vgl. Rossouw, 1991:121; Louw, 1998:58; Brunsdon, 2002:5). In die bemiddeling hiervan speel sake soos die Woord en gebed ' $n$ onontbeerlike rol. Een van die kritiese vrae binne 'n narratiewe pastoraat sou wees in watter rigting God iemand se storie wil oorskryf (Burger \& Simpson, 1996:83). Die narratief, daarenteen, rus swaar op die filosofiese onderbou van die poststrukturalis, Focault, en die sosiolinguis, Halliday, se denke (Milner \& O'Byrne, 2002:10) waarbinne sogenaamde grand narratives (algemene, tydlose waarhede) se rol vervaag. Binne 'n konsekwente narratiewe benadering sou die waarheid en gesag van die Skrif in gedrang kom en die begrip narratiewe pastoraat ' $\mathrm{n}$ anomalie verteenwoordig. (Narratiewe pastoraat word dus binne die raamwerk van hierdie artikel gekwalifiseer as 'n terapeutiese benadering wat vanuit die Skrif en die gesag daarvan vertrek, maar wat die sogenaamde teksanalogie van die narratief, dit is die verhale van mense, naas die Godsverhaal, soos geopenbaar in die Bybel, ernstig op te neem.)

\subsection{Skrifgebruik binne 'n narratiewe pastorale benadering}

In die lig van die voorafgaande, kom die belangrikheid van Skrifgebruik binne 'n pastoraal-narratiewe benadering na vore. Skrifgebruik word gedefinieer as katalisator vir die sogenaamde alternatiewe verhaal waarmee persone se dominante (probleemdeurdrenkte) verhale getransformeer word na unieke uitkomste of nuwe verhale van hoop. Binne die pastorale raamwerk, soos voorgestaan in hierdie artikel, word nie uitsluitlik op die menslike potensiaal staatgemaak om die probleemdeurdrenkte verhale te transformeer nie, maar primêr op die Godsverhaal soos geopenbaar in die Woord.

It is not enough that we employ both the rational and the imaginative ... Reason and imagination are organs of knowing ... but in themselves they are empty of content. They are wrong whenever they try to account for truth ... without taking into account the ultimate reality of God.

Uit hierdie aanhaling van Camery-Hoggat (2006:468) blyk die futiliteit van 'n pastoraat wat alleen op die verhale van mense staatmaak. Die realiteit van God, soos geopenbaar in die besondere openbaring (Woord), is die basis waarop 'n narratiewe pastoraat behoort te staan. Dit wil juis 'n samesmelting tussen die vasgeloopte mensverhaal en die transenderende Godverhaal bewerk. 
In hierdie artikel word aansluiting gevind by Louw (1998:430) se gedagte van organiese Skrifgebruik. Die begrip organies word gebruik om iets te verwoord van die beginsel dat die Skrif binne die pastorale situasie eerder vertolk moet word as wat dit homileties gebruik word. Dit beteken dat die pastoraat nie vanuit 'n bepaalde Skriftema vertrek wat op die situasie afgedwing word nie. Daar word eers na die relevante verhale geluister, waarna die pastor en noodlydende na die Skrif luister om te hoor wat dit vir die eksistensiële situasie te sê het. Louw (1998:431) beklemtoon die belangrike beginsel dat hierdie skema nie beteken dat die mensteks die inhoud van die Woordteks bepaal nie. Wat metodies gesproke eerste kom, is nie prinsipieel en inhoudelik eerste nie. Daarom word die organiese gebruik van die Skrif nie los gesien van gebed en die werking van die Heilige Gees nie.

Uiteraard is Skrifgebruik in die pastoraat 'n kwesbare onderneming. Müller (1996:17-19) meen dat die Woord verkeerd aangewend kan word wanneer dit die vasgeloopte pastorale gesprek moet "red" of as dit as bron vir oppervlakkige oplossings dien of wanneer die Skrif sodanig gebruik word dat dit uitloop op allerhande eksegetiese wangestaltes.

Verantwoordelike Skrifgebruik is egter die draer van die ware aard van die pastoraat en bring die onderskeidende eienskap in die proses in, wat menslike verbeelding nie kan nie. In die narratiewe pastoraat beteken dit dat die Bybel as kenbron van die verbeelde toekoms dien.

\subsection{Sinsfasilitering tydens aftrede}

Die spesifieke bydrae van hierdie artikel lê waarskynlik in die terminologie wat vervolgens verhelder sal word, te wete om aftrede as integrasionele taak te benader. Hiermee word bedoel dat die afgetredene begelei moet word tot 'n sinvolle integrasie van sy/haar verlede, hede en toekomsverhaal sowel as die hoopvolle verhaal van God om tot 'n positiewe sinsbelewing (sinsuitlewing) tydens aftrede te kom. Binne 'n Christelike denkraamwerk sal die sin van die lewe veral in die rigting van gehoorsaamheid aan die Here gesoek word. Dit beteken om 'n goeie rentmeester te bly van dit wat die Here hier op aarde aan my toevertrou het. Indien ' $n$ mens getrou bly aan die beginsel van die vorming van verhale oor tyd deur gebeurtenisse, geloofsdiskoerse en kontekstuele faktore (sosiale diskoerse), kan aanvaar word dat afgetredenes hulle aftrede waarskynlik aan die hand van hulle eie verhale sal uitleef. Waar hierdie verhale deurdrenk is van negatiewe diskoerse, soos teleurstelling 
gedurende die beroepsjare, vrees vir verlies tydens aftrede en onsekerheid oor die toekoms, kan verwag word dat potensiaalontsluiting tydens aftrede beperk sal wees. Hierdie beperkte potensiaalontsluiting kan veral versterk word deur die sosiale diskoerse wat 'n samelewing oor aftrede in stand hou. Wanneer die Godsverhaal hiermee saam gelees word, behoort hierdie fase egter in 'n meer positiewe lig gesien te word. Vander Steen (2004:183) wys byvoorbeeld op grond van die verhaal van Elia daarop dat God self die middele voorsien waarmee rentmeesterskap uitgeleef kan word. Dit suggereer dat die Godsverhaal oor hoopvolle elemente beskik waarmee die beperkende verhale positief getransformeer kan word.

Binne die Westerse samelewing, is die sosiale diskoerse oor aftrede oor die laaste aantal dekades deur veral twee beginsels beïnvloed. Aan die een kant is daar rede om te glo dat 'n wanbalans tussen beroeps- en persoonlike lewe in die Westerse samelewing ontwikkel het (vgl. Houston, 2005). Tydens die beroepsjare eis 'n loopbaan soveel van iemand dat hulle van hulle menswees beroof kan voel. Mense hunker dus na "bevryding" van die bande van arbeid (Charles \& James, 2005:183) wat tydens aftrede kan uitmond in 'n totale onttrekking uit die samelewing en geloofsgemeenskap, uit vrees vir verdere eise. Aan die ander kant is aftrede histories as tyd van losmaking en ontkoppeling gesien. Hier word gedink aan die sogenaamde ontkoppelingsteorie wat heelwat prominensie in die denke oor aftrede geniet (Hattingh, 1996:40). Die somtotaal hiervan is dat afgetredenes aan hulle omgewing onttrek, meer gefokus is op hulleself en uiteindelik gevoelens van nutteloosheid ervaar.

\section{Basisteoretiese vertrekpunte uit die boek Prediker: was daar, het dit gedoen, het die T-hemp ... wat nou!?}

Die volgende paragrawe poog om basisteoretiese beginsels oor arbeid en die sin van die lewe te vorm wat in berekening gebring behoort te word tydens die begeleiding van afgetredenes.

\subsection{Prediker as lewenskommentaar}

Vir die doeleindes van hierdie artikel word die boek Prediker gekies om basisteoretiese vertrekpunte te formuleer. Hierdie keuse berus hoofsaaklik op die feit dat Prediker oor die ganse lewe reflekteer. Die prediker kyk terug oor alles wat hy beproef het, om sin in die lewe te vind en hy reflekteer krities daaroor. Die boek Prediker vorm deel van die sogenaamde wysheidsliteratuur wat saam met boeke soos Spreuke en Job nadink oor die goddelike orde in die lewe en die mens se suksesvolle inskakeling daarby (Vosloo \& Van Rens- 
burg, 1999:735). Die prediker gaan evaluerend met die kernvraagstukke van die lewe om en lewer kommentaar daarop sodat die leser op voorkomende wyse uit sy ondervinding kan leer (Forsyth, 2005:19). In hierdie opsig is Prediker waardevol vir die afgetredene wat nadink oor die sinvolheid van die lewe tot sover geleef en sin probeer maak van dit wat nog voorlê. Voorts sal op eklektiese wyse opmerkings oor 'n aantal gedeeltes gemaak word wat op die lewe en arbeid van die mens betrekking het.

\subsection{Oënskynlike sinloosheid volgens Prediker}

\section{- $\quad$ Alles kom tot niks (Pred. 1:2; 12:8)}

Die boek word omarm deur die uitspraak van Prediker 1:2 en 12:8. Die Hebreeuse hebel word gewoonlik vertaal met "utterly senseless" (Forsyth, 2005:37). VanGemeren (1997:1003) verklaar hierdie begrip aan die hand van die voorbeeld van wasem - iets wat geen substansie het nie en betekenisloos is. Die feit dat hierdie uitspraak sowel die boek begin as afsluit, dui daarop dat die prediker nie sin in die dinge op aarde kon vind nie. "... even the wisest can make no sense of this world" (Shields, 2006:122). Hierdie siening dat alle dinge op aarde "utterly senseless" is, word ondersteun deur die waarnemings van die prediker in die volgende paragrawe.

\section{- $\quad$ Die grense van tyd (Pred. 3:1-15)}

Garrett (1993:297) poneer dat die sentrale gedagte van hoofstuk 3 nie soseer gesoek moet word in goddelike voorsienigheid nie, maar in die begrensing van tyd - en daarom die lewe op aarde. Die fokus val nie op die beginsel dat God bepaalde periodes soos 'n planttyd (3:2) en 'n oorlogstyd (3:8) voorsien nie, maar dat alle periodes eindig (3:2a). Die mens moet sy eie bestaan, volgens Prediker, binne hierdie begrensde tyd verstaan.

\section{- $\quad$ Die sinloosheid van arbeid (Pred. 2:18-19; 4:4-8)}

Die besittings wat die mens deur arbeid versamel, bevredig nie (Maxwell, 2007:62). Boonop kan dit in die hande van vreemdes beland wat dit nie waardeer nie (2:18-19). Daar is dus nie 'n direkte verband te lê tussen inset en beloning nie, aangesien "undeserving successors" daarmee heengaan "like casting pearls before swine" (Brown, 2000:36). Arbeid is dus 'n gejaag na wind (4:4). Hierdie waarneming word geïntensifiseer deur die uitspraak dat die een wat hande vou en die een wat werk albei na wind jaag (4:5-6). Arbeid kan dus nie die hoogste sin van die mens se bestaan wees nie, maar het alleen waarde omdat die mens, terwyl hy/sy daarmee 
besig is, sy/haar roeping as rentmeester beoefen (Towner, 1997:315).

\section{- $\quad$ Die waardeloosheid van rykdom (Pred. 5:9-6:9)}

Die prediker sien arbeid en rykdom in 'n soortgelyke lig. lemand anders pluk die vrug daarvan (5:10; 6:2). Rykdom en goed moet dus op geen stadium as doel in die lewe of van waarde geskat word nie (Garrett, 1993:314). Dit bring net verantwoordelikheid mee en die angs dat die eienaar dit nie self kan geniet nie. Die begrensing van tyd plaas nog verdere druk op die waarde van rykdom, aangesien die doogebore baba (6:3) en die ryke albei vir die graf bestem is (6:6).

\section{- $\quad$ Die skerp kant van ouderdom (Pred. 12:1-7)}

Die onafwendbare ouderdom word deur Prediker die "swaar dae" (21:1) genoem. Hierdie swaar dae word gekonstitueer deur die agteruitgang van liggaamlike funksies kenmerkend van chronologiese veroudering. Prediker beskryf dit op 'n wyse wat die aandag van die leser boei deur simbolies na sekere liggaamsfunksies te verwys. "Dit is die tyd wanneer die wagters van die huis sal bewe ... en die malers ophou maal ..." (12:3) verwys in alle waarskynlikheid na die hande en arms wat begin bewe en die tande van die bejaarde wat min geraak het (Forsyth, 2005:148). Wat opmerklik is, is dat hierdie veroudering op die dood uitloop (12:7) en daarom staan die oproep dat God reeds in die jongdae geken moet word baie sterk uit teen die agtergrond van agteruitgang in die ouderdom (Olyott, 1992:63).

\subsection{Sin volgens Prediker}

- $\quad$ Twee vaar beter as een (Pred. 4:9-12)

Die leser van Prediker moenie die hebel-omarmingsuitspraak sodanig verstaan dat niks op aarde van waarde is nie. Oënskynlik wil dit so voorkom. Tog bejeën Prediker die verhoudings tussen mense met agting. Sin in die aardse bestaan word juis in die helpende verhoudings tussen mense gevind (vgl. ook Gen. 2:18) Hierdie helpende verhouding word in Prediker 4:9-11 belig: twee arbeiders se koalisie lewer groter individuele loon vir albei op (v. 9); die alleenvallende is gelukkig wanneer daar iemand byderhand is om hom/ haar op te help (v. 10); twee mense is beter teen die koue verskans en wanneer mense saam is, word die weerbaarheid van die individu verhoog (Murphy, 1992:42). Vers 12b dien as 'n bevestiging dat meervoud beter is as enkelvoud. Alhoewel die prediker nie probeer sê dat mense saam moet wees ten einde bestaansin te hê nie, is 
hierdie positiewe uitsprake opvalllend teen die agtergrond van die hebel-uitsprake. Inderdaad is hierdie lewe goed, of ten minste beter, in die lig van kameraadskap - iets wat sin gee in 'n anders sinlose wêreld (Shields, 2006:153).

\section{- $\quad$ Sin is geleë in die verhouding met God (Pred. 12:9-14)}

Indien aanvaar word dat Prediker omarm word deur die hebeluitsprake van Prediker 1:2 en 12:8, moet saamgestem word met die siening dat Prediker 12:9-14 'n naskrif of samevatting van die vorige uitsprake is (Murphy, 1992:124). Op grond van taal, styl en ander parallelle meen Garrett (1993:345) dat daar nie rede is om te aanvaar dat hierdie samevatting iemand anders se werk is nie. Nuwere navorsing, soos dié van Brown (2000:9-14) en Shields (2006:237) meen egter dat hierdie naskrif die werk van een of meer epiloë bevat. In alle gevalle word die uitsprake hier egter as kanoniek aanvaar, aangesien dit beskou word as 'n gevolgtrekking of interpretasie van die leringe van die prediker. Van belang is die uitspraak van v. 13: "Die slotsom van alles wat jy gehoor het, is dit: Dien God en gehoorsaam sy gebooie." Alle menslike pogings om sin te vind word verstaan teen die agtergrond dat die mens se hoogste goed is om binne 'n verhouding met God te leef. Olyott (1992:66) meen dat hierdie dien vanuit die hart wat voor die goedheid van God buig, nie anders kan as om in 'n dankbaarheidslewe uit te mond nie, soos gesien in die onderhouding van die gebooie. Die brug wat vers 14 slaan na rekenskap, dui op die prediker se besef dat daar 'n beloning, 'n prys, wag vir die lewe wat sy hoogste sin en doel in die diens van die Here gevind het (Olyott, 1992:68).

\subsection{Basisteoretiese gevolgtrekkings uit die boek Prediker}

Die volgende riglyne sou verreken kon word binne die narratiewe pastoraat aan die afgetredene:

- Die antwoord op die vraag, "Was daar, het dit gedoen, het nou die T-hemp - wat nou!?", is volgens Prediker "ontnugtering", die gewaarwording dat alles 'n gejaag na wind is. Hierdie gewaarwording verteenwoordig 'n hopeloosheid in die lig van die mens se soeke na sin.

- Die lewe op aarde is begrens deur die verganklikheid van die mens.

- Binne die grense van geboorte en sterfte is die mens besig met werk wat tydelik is en slegs tydelike vervulling meebring. 
- Die menslike lewe loop onafwendbaar uit op die verskrikking van oudword en uiteindelik sterwe.

- Die treurige mensverhaal word getransendeer deur die sin wat op aarde geleë is binne helpende verhoudings met ander.

- Die hopeloosheid van die mens kry ten diepste sin in die verhouding met God wat die aardse swaar, ontnugtering en vrae transendeer wanneer ons die tydelike met die ewige verwissel.

- Die prediker kan ons tot die insig bring dat die aardse slegs sin het in 'n verhouding met God en die naaste.

\section{Aftrede fenomenologies beskou}

Metateoretiese besinning is nodig ten einde 'n brug tussen die voorafgaande basisteorie en die bedieningswerklikheid van die afgetredene te slaan. Derhalwe word aftrede vervolgens as verskynsel (lewenswerklikheid) beskou deur uit dissiplines te put wat raakvlakke met die onderwerp deel (Venter, 1996:189).

\subsection{Historiese oorsig}

As sosiale instelling het aftrede 'n relatief jong geskiedenis. In die algemeen word die verskyning van aftrede met die opkoms van kapitalisme en Marxisme in verband gebring (De Beer, 1998:31). Voor hierdie periode het persone arbeid as 'n lewenslange aktiwiteit sonder duidelike grense tussen begin en einde beskou. Om te werk is ook as geestelike roeping beskou. Die uitspraak van Paulus in 2 Timoteus 3:10b is in hierdie verband betekenisvol: "As iemand nie wil werk nie, moet hy ook nie eet nie." Selfs al maak Augustinus in die vierde eeu onderskeid tussen die sogenaamde vita activa en vita contemplative (aktiewe lewe en bepeinsing van die lewe), was daar geen aanduiding van 'n algehele staking van arbeid nie (De Klerk, 2005:474). Veral twee faktore het die praktyk van aftrede gevestig, te wete die langer lewensverwagting van mense en die daarstelling van finansiële voorsiening wat afgetredenes volhoubaar in stand kon hou (De Klerk, 2005:475). Vandag word aftrede as deel van die normale lewensiklus beskou en word daar in die volksmond na aftrede as die sogenaamde goue jare verwys. Inherent hieraan is die persepsie dat aftrede as kroon sowel as die beloning vir die mens se arbeid gesien kan word (Brunsdon, 2006:82) 


\subsection{Aftrede as komplekse fenomeen}

As verskynsel wat deur die loop van die geskiedenis ontwikkel het, het aftrede homself egter as 'n komplekse fenomeen openbaar. Hierdie stelling berus op die eiesoortige uitdagings wat aftrede na vore bring. Enkele sake is relevant:

\section{- $\quad$ Die weg waarlangs afgetree word en die ingesteldheid teenoor aftrede}

Aftrede kom in die beroepslewens van mense binne die gesigseinder om verskeie redes. Die bekendste hiervan is dat ' $n$ persoon die sogenaamde aftree-ouderdom van sy/haar werkgewer bereik het. Daar is egter ook ander faktore wat die periode van aftrede kan inlei, soos aftrede weens regstellende aksie of die ekonomiese stand van 'n maatskappy. Hierdie faktore het 'n invloed op hoe 'n persoon sy/haar aftrede beleef (De Beer, 1998:76). Indien iemand voel dat hy/sy weens onregverdigheid moes aftree, kan 'n negatiewe ingesteldheid teenoor aftrede in alle waarskynlikheid geantisipeer word.

\section{- $\quad$ Aftrede as inleier van die sogenaamde oudag}

Omdat aftrede binne die Suid-Afrikaanse konteks met 'n bepaalde ouderdom geassosieer word, is aftrede een van die mees tasbare aanduidings dat ' $n$ persoon besig is om chronologies te verouder. Die sogenaamde aftree-ouderdom in Suid-Afrika blyk vandag iewers tussen 55 en 65 te wees. Hoewel die sogenaamde aftree-ouderdom nie noodwendig 'n refleksie op 'n persoon se werksvermoë is nie, verteenwoordig dit 'n waterskeiding in persone se persepsie rondom die belewing van hulle ouderdom. Hierdie persepsie word versterk deur bepaalde fisiologiese veranderings wat vanaf 'n sekere ouderdom by mense sigbaar word, soos osteoperose en hormonale veranderings by vroue en verlies aan liggaamskrag en prostaatprobleme by mans (Thoburn \& Powling, 2000:191).

\section{- $\quad$ Aftrede as sein dat my doel gedien is}

'n Beroep is vir die meeste persone 'n verlengstuk van hulle persoonlikheid. Arbeid word ook dikwels as 'n roeping beskryf (Clinton, 2001:859). In die lig hiervan beleef die afgetredene 'n bepaalde nutteloosheid wanneer die beroepstuig neergelê moet word. Gevoelens dat die afgetredene se doel uitgedien is, is nie vreemd nie. Hierdie ervaring kleur die eerste gedeelte van die aftreejare negatief. 


\section{- $\quad$ Aftrede as uitdaging vir finansiële vermoëns}

Binne die huidige ekonomiese klimaat en die langer lewensverwagting van mense, beleef afgetredenes gewoonlik ekonomiese druk. Die verskynsel dat pensioenarisse hulle pensioen oorleef, is nie vreemd nie. Indien hiermee saam die stygende lewens- en mediese koste in ag geneem word, is die hopeloosheid van hedendaagse afgetredenes begryplik (Koenig \& Lawson, 2004:6).

\section{- $\quad$ Aftrede as vloeibare fase}

Dit sou moeilik wees om die lewensgevoel tydens aftrede onder een noemer te bring, veral in die lig van die vloeibare aard van hierdie periode. Hiermee word gedink aan die sogenaamde fases wat in die periode ná staking van die loopbaan volg. Dit wissel van die sogenaamde wittebroodsfase tot die terminale fase (vgl. Brunsdon, 2006). De Klerk (2005:475) skryf: "Die eerste twee maande is 'n tipe vreedsame rewolusie, maar dit kan op 'n wrede wyse opgevolg word deur 'n tydperk van verliesbelewing, 'n soeke na sin en selfs gepaardgaande depressie." Hierdie sogenaamde fases van aftrede skep aanvanklik onsekerheid in terme van wat die afgetredene van hierdie lewensfase kan verwag.

\section{- $\quad$ Aftrede as pylvak}

Tensy persone spesifieke beplanning aan aftrede koppel (soos 'n nuwe beroep, verdere studie en so meer), word hierdie lewensfase dikwels as 'n finale fase of "pylvak" beskou (Cloete, 2005:34). Hiermee gaan 'n besef van die begrensing van die lewe gepaard soos wat die bejaarde akademikus Bobbio in sy boek, Old age and other essays (2001) beskryf. Baie aksies word in die lig van 'n "laaste keer" beskou, aangesien sekere lewenstake nie weer verrig gaan word nie. "Ons is nou klaar hiermee of daarmee", word 'n oorkoepelende lewensgevoel wat inhiberend op die afgetredene inwerk.

\section{- $\quad$ Aftrede as geleentheid}

Persone wat in die gelukkige posisie verkeer om oor die gesondheid en middele te beskik, wat 'n bevredigende loopbaan gehad het en pro-aktief vir aftrede beplan het, sal uiteraard in hierdie fase 'n wonderlike geleentheid sien (Squire, 2002:28) Inderdaad hoef aftrede nie iets te wees wat "oorleef" hoef te word nie, maar wat "geleef" kan word (Fourie \& Codrington, 2004:225).

Uit die voorafgaande blyk duidelik dat aftrede, soos ander lewensfases, nie ongekompliseerd is nie. Aftrede kan vanweë die talle uitdagings daaraan verbonde, 'n kwesbare periode (Fourie \& Co- 
drington, 2004:223) in die lewens van mense verteenwoordig. Om die meeste hiervan te maak, kan as 'n uitdaging beskou word (Arp \& Arp, 1996:17).

\section{Die eietydse Suid-Afrikaanse konteks as katalisator vir futiliteit tydens aftrede}

Daar sou moeilik oor aftrede besin kon word sonder om die konteks waarbinne dit geskied in ag te neem, veral binne die raamwerk van die narratief waar die sosiale diskoerse van die leefomgewing so 'n belangrike rol speel. Die konteks van hierdie artikel is die sogenaamde nuwe Suid-Afrika. Die term nuwe Suid-Afrika is 'n term wat sedert 1994 gangbaar geword het toe 'n nuwe demokratiese bedeling alhier gevestig is. Van belang vir hierdie artikel is watter lewensgevoel die Suid-Afrikaanse landskap kenmerk. Volgens Swanepoel (2007:129) is die entoesiasme vir die nuwe Suid-Afrika aan die kwyn en die glans van die reënboognasie besig om te verdof. Eloff (2007:122) meen dat sake soos misdaad, korrupsie en swak dienslewering alle Suid-Afrikaners negatief stem, maar dat die tradisionele blanke Suid-Afrikaner in besonder geraak word deur die gevolge van regstellende aksie, verlies van historiese identiteit, politieke en ekonomiese mag. Dit sou dus nie ongegrond wees om te beweer dat persone wat tans aftree dit binne die raamwerk van 'n onsekere lewensgevoel doen nie.

Buiten hierdie onseker lewensgevoel, is daar spesifieke sake wat negatief op die leefwêreld van die afgetredene sal inspeel. Hieronder tel stygende lewens- en mediese koste (Kruger, 2008), persoonlike veiligheid (Schröder, 2008) en kinders wat die land verlaat (Benghiat, 2008:41).

\section{Enkele praktykteoretiese riglyne vir die fasilitering van aftrede as integrasionele taak}

In hierdie afdeling word gepoog om die fasilitering van aftrede as integrasionele taak deur enkele riglyne te konstrueer. Die formasie van 'n narratiewe pastoraat word aan die hand van die vier bewegings gedoen wat by afdeling 2.2 bespreek is.

\subsection{Algemene riglyne vir die fasilitering van aftrede as integrasionele taak}

- Daar moet deurgaans in gedagte gehou word dat aftrede 'n komplekse lewensfase verteenwoordig in die lig van legio faktore wat op afgetredenes se denke en omstandighede inwerk. 
- Ten einde die afgetredene wat neig na futiliteit en sinloosheid gedurende hierdie periode te begelei tot 'n sinvolle integrasie van alle geleefde ervarings en toekomsverwagtings, moet hulle aangemoedig word om hulle verlede-, hede- en toekomsverhale te vertel. Die pastor moet gewillig wees om 'n reisgenoot op hierdie reisverhaal te word.

- Aftrede en die persoon se plek binne hierdie lewensfase kan meer positief ervaar word wanneer verhale van hoop saam met hulle gekonstrueer (verbeeld) word in die lig van God se Woord.

\subsection{Die hoor van die noodverhaal}

Waarin is die nood van die afgetrede verteller geleë? Hoekom het hulle onttrek en hoekom worstel hulle om sin te vind? Om te luister na die verledeverhaal, beteken om te hoor waarom mense staan waar hulle op die oomblik staan.

\subsection{Die hoor van die verledeverhaal}

Hier moet veral fyn geluister word na die verledeverhaal waarin die noodverhaal ingebed is. Langs watter weg is aftrede bereik en met watter vooruitsigte? Die gesondheid, lewensomstandighede, materiële vooruitsigte en stand van verhoudings met naasbestaandes mag waardevolle suggesties wees waarom 'n bepaalde verhaal bestaan.

\subsection{Die hervertelling van die verledeverhaal}

Met hierdie beweging word die begin van nuwe perspektiewe sigbaar. Die belangrike uitdaging is die herformulering van verhale en persepsies wat problematies is. Aangesien dit ook die rede is waarom mense in negatiewe diskoerse vasval, moet hierdie verhale weer vertel word terwyl die Godsverhaal ingeweef word. Uit die basisteoretiese besinning oor die boek Prediker wag daar heel moontlik bevrydende ontdekkings. Die afgetredene mag ervaar dat sy/haar belewenisse nie so vreemd is nie en dat die groter familie van God se kinders ook binne bepaalde noodverhale vasgeval was. Hierdie beweging van die narratiewe pastoraat verteenwoordig ' $n$ opwindende onderneming.

\subsection{Die konstruksie van 'n hoopvolle toekomsverhaal (integrasie)}

Wanneer die ou, verlammende diskoerse gedekonstrueer is, kan saamgedink word oor die konstruksie van 'n nuwe toekomsverhaal. 
Met die waarde wat die Woord aan die mens en gebeure toeken, word nou met 'n nuwe maatstaf gemeet en geweeg. Persoonlike verhale word nou in die lig van die Woord beskou. 'n Belangrike sleutel is dat daar nou anders gedink en geleef kan word. Belangrike vrae vir die afgetredene handel, in die lig van Prediker, nie oor wat het ek bereik nie, maar (W)wie langs my is en hoe ek vorentoe leef. In die lig van die komende Godsryk kry ons aardse arbeid, lewe, lief en leed nuwe waarde. Daarom kan mense in elke lewensfase hoopvol leef in die wete dat die beste nog vir ons voorlê.

\section{Slotopmerkings oor aftrede as integrasionele taak}

Hierdie artikel het gepoog om 'n nuwe rigting aan te dui vir die wyse waarop afgetredenes in ' $n$ komplekse lewensfase behoort te leef. Om dit te sien as 'n periode van integrasie kan deur middel van 'n narratiewe pastoraat meewerk tot die daarstel van 'n gebalanseerde perspektief op die laaste skof. In die lig van die Woord is dit nie wat in die verlede lê wat bepalend is nie, maar dit wat voorlê. Hierdie integrasie van die mens en die Godsverhaal het potensiaal om afgetredenes aktief vir hulle omgewing en die koninkryk van God hier op aarde te hou.

\section{Geraadpleegde bronne}

ANDERSON, H.D. \& GOOLISHIAN, H. 1992. The client is the expert: a not knowing approach to therapy. (In McNamee, S. \& Gergen, K. Therapy as social construction. London: Sage. p. 24-37.)

ARP, D. \& ARP, C. 1996. The second half of marriage. Grand Rapids: Zondervan.

BENGHIAT, L. 2008. My kinders emigreer. Lig, 40-41, Mei.

BEZUIDENHOUT, J.P. 2005. Volwassewording as problematiek in pastorale konteks. Bloemfontein: Universiteit van die Vrystaat. (D. Th.-proefskrif.)

BOBBIO, N. 2001. Old age and other essays. Cambridge: Polity.

BROWN, W.P. 2000. Ecclesiastes. Louisville: John Knox.

BRUNSDON, A.R. 2002. Die selfmoordkontemplerende adolessent: 'n ontwerp vir pastoraal-terapeutiese begeleiding vanuit ' $n$ verbondsparadigma. Bloemfontein: Universiteit van die Vrystaat. (M.Th.-skripsie.)

BRUNSDON, A.R. 2006. Pastoraat aan die afgetrede egpaar deur kanker geaffekteer: 'n narratiewe benadering. Bloemfontein: Universiteit van die Vrystaat. (Ph. D.-proefskrif.)

BURGER, C. \& SIMPSON, N. 1996. Poorte vir die genade. Kaapstad: Lux Verbi.

BYBEL 1983. Die Bybel. Nuwe vertaling. Kaapstad: Bybelgenootskap van SuidAfrika.

CAMERY-HOGGAT, J. 2006. God in the plot: storytelling and the many-sided truth of the Christian faith. Christian scholars review, 35(4):461-470. 
CHARLES, N. \& JAMES, E. 2005. Gender, job insecurity and the work-life balance. (In Houston, D.M., ed. Work-life balance in the 21st century. New York: Palgrave Macmillan. p. 170-188.)

CLINTON, T., ed. 2001. The soul care Bible. Nashville: Thomas Nelson.

CLOETE, B. 2005. In die pylvak. (In Janse van Rensburg, F. \& Coetzee, P., reds. God vergeet jou nooit! Vereeniging: Christelike Uitgewersmaatskappy. p. 34-35.)

DE BEER, E.J. 1998. 'n Teologies-etiese beoordeling van aftrede. Potchefstroom: PU vir CHO. (Th.M.-verhandeling.)

DE JAGER, J.J. \& MÜLLER, J.C. 2002. Dekonstruksie van tradisionele probleem-realiteite: 'n narratief-pastorale perspektief. Hervormde teologiese studies, 58(3):1221-1239.

DE KLERK, B.J. 2005. 'n Liturgie van aftrede. In die Skriflig, 39(3):463-485.

DE WET, F.W. 2006. Die aanwending van Rolf Zerfass se handelingswetenskaplike model in prakties-teologiese teorievorming: 'n gereformeerde perspektief. In die Skriflig, 40(1):57-87.

EBERSHOLE, P. \& HESS, P. 1990. Towards healthy ageing: human needs and nursing response. St. Louis: Mosby.

ELOFF, T. 2007. Is daar 'n "nuwe Afrikaner" vir die "nuwe Suid-Afrika"? Koers, 72(1):119-126.

ERIKSON, E.H. 1965. Childhood and society. Harmondsworth: Penguin.

FORSYTH, D. 2005. Ecclesiastes as an authoritative foundation for teaching life-skills to youth today. Pretoria: University of Pretoria. (Ph. D. dissertation.)

FOURIE, L. \& CODRINGTON, G. 2004. Mind over money. Cape Town: Penguin.

FREEDMAN, J. \& COMBS, G. 1996. Narrative therapy: the social construction of preferred realities. New York: Norton.

GARRETT, D.A. 1993. The new American commentary: Proverbs, Ecclesiastes, Songs of songs. Nashville: Broadman.

HATTINGH, S. 1996. Theories of ageing. (In Hattingh, S., ed. Gerontology: a community health perspective. Halfway House: Thompsons. p. 24-51.)

HOUSTON, D.M., ed. 2005. Work-life balance in the 21st century. Hampshire: Palgrave Macmillan.

JANSE VAN RENSBURG, J. 2000. The paradigm shift. Pretoria: Van Schaik.

JANSE VAN RENSBURG, J. 2007. Voortsetting van die epistemologiese diskoers in die praktiese teologie: in gesprek met J-A. van den Berg. Praktiese teologie in Suid-Afrika, 22(2):61-80.

KAYE, L.W., ed. 2005. Perspectives on productive aging: social work with the new aged. Washington: National Association of Social Workers.

KOENIG, H.G. \& LAWSON, D.M. 2004. Faith in the future. Philadelphia: Templeton.

KRUGER, M. 2008. Skuld is die grootste vreter van aftreegeld. http://www. news24.com./Sake/Jou_Geldsake/Algemene_Geldsake/Algemene_Gelds ake/0,,6-102-1609_2320576,00.html Datum van gebruik: 11 Jun. 2008.

LOTTER, G.A. 2007. Pastorale teologie: voëlvlug en (voorlopige) landing. Potchefstroom: NWU. (Intreerede.)

LOUW, D.J. 1998. Pastoraat as vertolking en ontmoeting. 3e uitg. Kaapstad: Lux Verbi.

MAXWELL, J.C. Misluk suksesvol. Kaapstad: Struik Christelike Boeke. 
MILLER, C.A. 2004. Nursing for wellness in older adults: theory and practice. Philadelphia: Lippincott Williams Wilkins.

MILNER, J. \& O'BYRNE, P. 2002. Brief counselling: narratives and solutions. New York: Palgrave.

MORGAN, A. 2000. What is narrative therapy? Adelaide: Dulwich.

MÜLLER, J.C. 1996. Om tot verhaal te kom: pastoral gesinsterapie. Pretoria: RGN.

MÜLLER, J.C. 2000. Reisgeselskap: die kuns van pastorale gesprekvoering. Wellington: Lux Verbi.BM.

MURPHY, R. 1992. Word Biblical commentary: Ecclesiastes. Waco: Word Books.

O'HANLON, B. 1994. The third wave: can a brief therapy open doors to transformation? The family networker, 19-29, Nov./Dec.

OLYOTT, S. 1992. A life worth living. Welwyn: Evangelical Press.

ROSSOUW, P.J. 1991. Die diakonologie: teologiese basisvrae. Tydskrif vir Christelike wetenskap, 1 \& 2:120-133.

SCHOEMAN, K. 2008. NG kerk-lidmate: verbuikers wat kies? Kruisgewys, 8 (2):6-7.

SENEKAL, D.P. 2006. Die funksionering van Bybelse inhoude in 'n narratiefpastorale gesprek. Praktiese teologie in Suid-Afrika, 21(2):134-146.

SHIELDS, M.A. 2006. The end of wisdom. Winona Lake: Eisenbrauns.

SHRÖDER, H. 2008. Nou is ons keelvol. www.breede.com./article.asp?News ID=7826 Datum van gebruik: 11 Jun. 2008.

SQUIRE, A. 2002. Health and well-being for older people. Edinburgh: Baillière Tindall.

STASSEN, S.L. 2004. Die benutting van die Rutverhaal in die pastoraalterapeutiese begeleiding van onderdrukte en getraumatiseerde vroue. Bloemfontein: Universiteit van die Vrystaat. (M.Th.-verhandeling.)

SWANEPOEL, J. 2007. My regte! Jou regte? Kom ons praat. Koers, 72(1):129141.

THOBURN, M. \& POWLING, S. 2000. The relate guide to loving in later life. London: Vermilion.

TOWNER, W.S. 1997. Ecclesiastes. (In The new interpreter's Bible. Vol. 5. Nashville: Abingdon. p. 267-360.)

VAN DEN BERG, J-A. 2006. 'n Verandering in tongval ...? 'n Verwoord-(-beelding)ing van pastoraal-teologiese perspektiewe. Praktiese teologie in Suid-Afrika, 21(2):164-181.

VAN DER WALT, B.J. 2007. Transforming power: challenging contemporary secular society. Potchefstroom: ICCA.

VAN WYK, C. \& MARAIS, F. 2005. Ore om God se alternatiewe verhaal te hoor. Kruisgewys, 5(3):17-20.

VANDER STEEN, D.W. 2004. A Biblical perspective on stewardship: a world view on giving. (In Hulst, J.B., ed. Christian world view and scholarship. Melbourne: Amani. p 180-199.)

VANGEMEREN, W.A., ed. 1997. New international dictionary of Old Testament theology and exegesis. Vol. 1. Grand Rapids: Zondervan.

VENTER, C.J.H. 1996. Die Woord in die werklikheid: wetenskapsteoretiese perspektiewe op die diakoniologie. In die Skriflig, 29(1 \& 2):181-202.

VOSLOO, W. \& JANSE VAN RENSBURG, F., reds. 1999. Die Bybellennium eenvolumekommentaar: die Bybel uitgelê vir eietydse toepassing. Vereeniging: Christelike Uitgewersmaatskappy. 
WHITE, M. \& EPSTON, D. 1990. Narrative means to therapeutic ends. New York: Norton.

ZERFASS, R. 1974. Praktische Theologie als Handlungswissenschaft. (In Klostermann, F. \& Zerfass, R. Praktische Theologie Heute. Munchen: Kaiser. S. 164-177.)

\section{Kernbegrippe:}

aftrede

futiliteit

integrasie

kritiese lewensfase

narratiewe pastoraat

Prediker

\section{Key concepts:}

critical life phase

Ecclesiastes

futility

integration

narrative pastorate

retirement 